
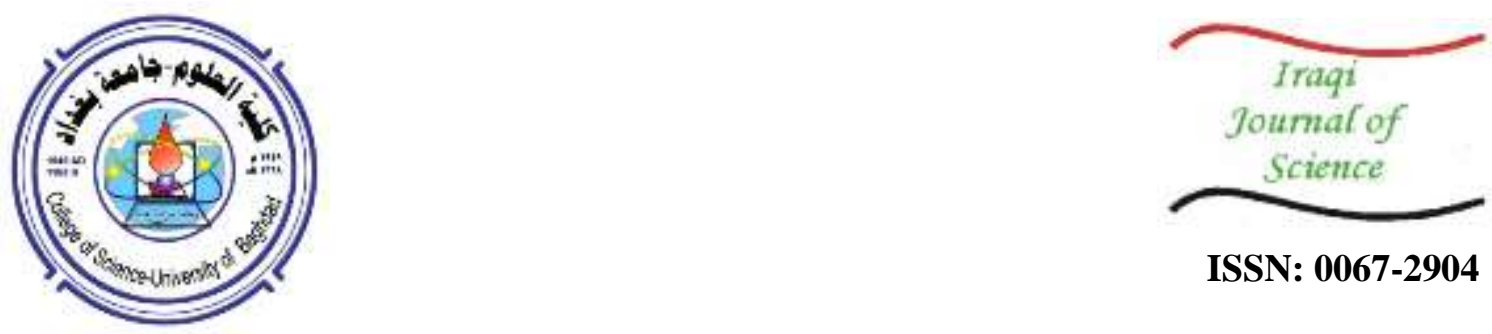

ISSN: 0067-2904

\title{
Studying the Effect of Annealing on Optical and Structure Properties of Zno Nanostructure Prepared by Laser Induced Plasma
}

\author{
Safa Kamal Mustafa*, Raied K. Jamal, Kadhim Abdulwahid Aadim
}

Department of Physics, Collage of Science, University of Baghdad, Baghdad, Iraq

\begin{abstract}
In this paper, Zinc oxide were deposited on a glass substrate at room temperature (RT) and two annealing temperatures $350^{\circ} \mathrm{C}$ and $500^{\circ} \mathrm{C}$ using laser induced plasma technique. $\mathrm{ZnO}$ nanofilms of $200 \mathrm{~nm}$ thickness have been deposited on glass substrate. X-RAY diffraction (XRD), atomic force microscopy and UV-visible spectrophotometer were used to analyze the results. $\mathrm{XRD}$ forms of $\mathrm{ZnO}$ nanostructure display hexagonal structure with three recognized peaks (100), (002), and (101) orientations at $500^{\circ} \mathrm{C}$ annealing temperature. The optical properties of $\mathrm{ZnO}$ nanostructure were determined spectra. The energy gap was $3.1 \mathrm{eV}$ at $300{ }^{\circ} \mathrm{C}$ and $3.25 \mathrm{eV}$ at $500^{\circ} \mathrm{C}$ annealing temperature.
\end{abstract}

Keywords: $\mathrm{ZnO}$ nanostructure, annealing temperature, laser induced plasma.

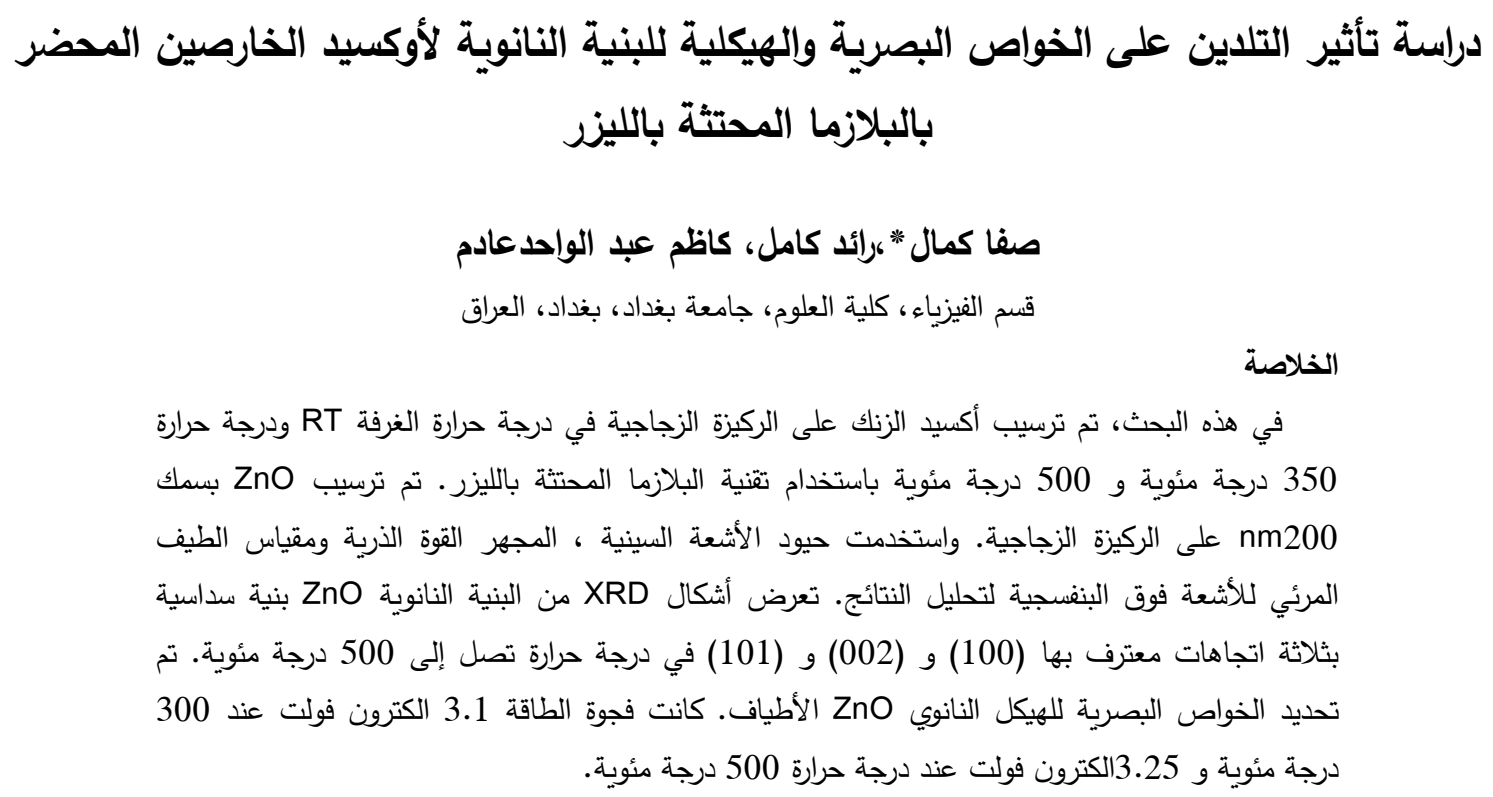

\section{Introduction}

$\mathrm{ZnO}$ is a semiconductor material, it has numerous applications because they have direct and great energy gap $3.3 \mathrm{eV}$ that near to $\mathrm{UV}$ region. $\mathrm{ZnO}$ have plentiful opto-electronic application in solar cells, spintronic [1, 2] and laser diodes (LDs) [3], light emitting diodes (LEDs) [4]. ZnO is n-type semiconductor material because this material has inner structural flaws like oxygen and zinc spaces or interstitial situations in a lattice [3]. 
Numerous mechanisms have been utilized to manufacture nanostructured thin films for $\mathrm{ZnO}$, such as thermal evaporation [5], magnetron sputtering [3], sputtering [6], chemical vapor [7] or ion-beam assisted [8]. One of the most common and attractive techniques used to prepare nanostructure thin films that have a characteristic is laser induced plasma (LIP) technique [9]. Laser induced plasma (LIP) technique is using to obtain high quality nanofilms of metal oxide materials [10]. The advantage of (LIP) over there techniques is quite easy to produce multilayered films of different materials [11].

\section{Experimental details}

$\mathrm{ZnO}$ nanopowder with purity (99.99\%) has been used in this work. The $\mathrm{ZnO}$ nanopowder was pressed as a tablet using piston. The $\mathrm{ZnO}$ tablet has $(2 \mathrm{~cm})$ diameter and $(1 \mathrm{~cm})$ thickness. Glass substrates of $(2.5 \times 7.5) \mathrm{cm}^{2}$ are cleaned by ultrasonic device using water for (10 minutes) and then use acetone for (10 minutes). Finally, it dried in an oven.

$\mathrm{ZnO}$ films were deposited on glass substrate using LIP technique at RT, as shown in Figure-1. $\mathrm{Nd}$ :YAG laser source with $(\lambda=1064 \mathrm{~nm})$ at pressure $\left(2.5 \times 10^{-2} \mathrm{mbar}\right)$ has been used to prepare the $\mathrm{ZnO}$ films. The distance between target and substrate was $(1.5 \mathrm{~cm})$. After vacuum chamber was done, three films were deposited at laser energy $600 \mathrm{~mJ}$ and number of shoot was 400 pulses. To determine the thickness of films, the optical interferometer method was used. The thickness of $\mathrm{ZnO}$ nanofilms were $(200 \mathrm{~nm})$. Two nanofilms were heated at $\left(350^{\circ} \mathrm{C}\right.$ and $\left.500^{\circ} \mathrm{C}\right)$ temperatures for two hours using a thermal oven.

The structural properties of the nanofilms for $\mathrm{ZnO}$ were examined using XRD analysis type (SHIMADZU6000 X-ray diffract meter system). The morphological characteristics of nanofilms were studied using atomic force microscope (AA3000 type). The optical properties of nanofilms were examined using (UV/ Visible SP-8001 spectrophotometer).

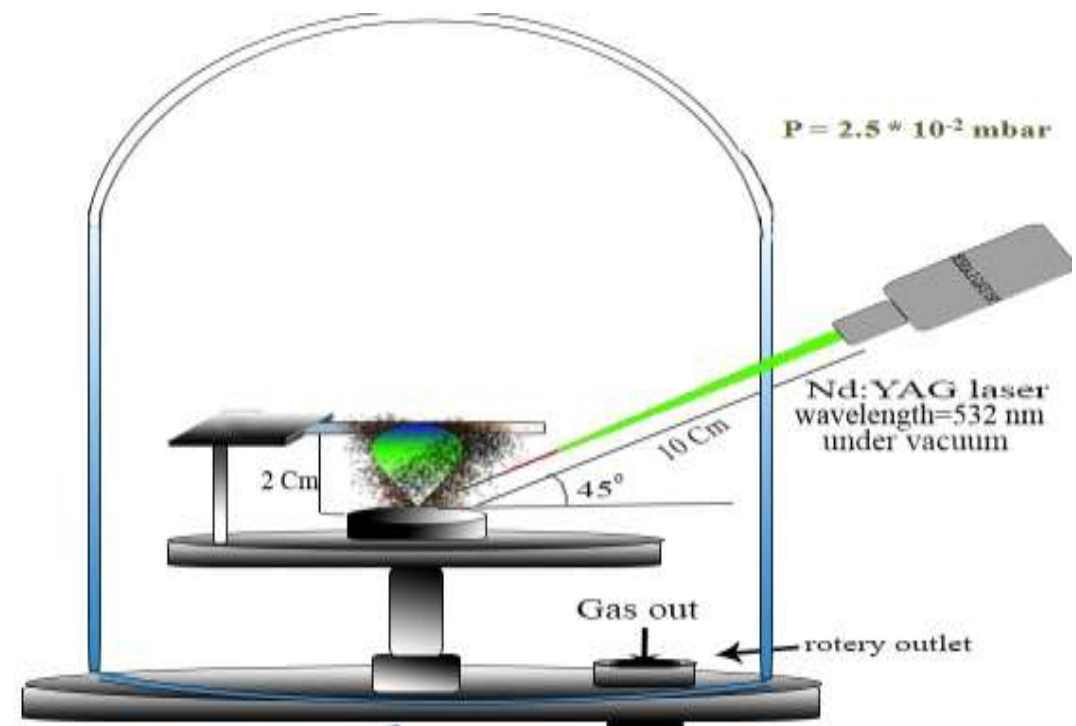

Figure 1-Schematic diagram of LIP with $(\lambda=1064 \mathrm{~nm})$

\section{Results and discussion}

XRD forms of $\mathrm{ZnO}$ nanofilms at different annealing temperatures are shown in Figure-2. XRD pattern for nanofilms showed polycrystalline structure. In Table-1, many dominant strongest peaks with their $d$ spacing, full width at half maximum (FWHM) and diffraction angle values of $\mathrm{ZnO}$ nanofilms with two annealing temperature $350^{\circ} \mathrm{C}$ and $500^{\circ} \mathrm{C}$ are shown. The mean grain size of the nanofilm calculated by using Scherr's equation [12]:

$$
\tau=\frac{K \lambda}{\beta \cos \theta}
$$

Where: $(\tau)$ is the mean size of the ordered (crystalline) domains, which may be smaller or equal to the grain size; $(K)$ is a dimensionless shape factor, with a value close to unity. The shape factor has a typical value of about 0.9 , but varies with the actual shape of the crystallite; $(\lambda)$ is the Xray wavelength; $(\beta)$ is the line broadening at FWHM, after subtracting the instrumental line broadening in radians. $\left(\theta^{\prime}\right)$ is the Bragg angle. 
The peaks of $\mathrm{ZnO}$ were seen more clearly at $500{ }^{\circ} \mathrm{C}$, where note that the intensity of peaks increase with increasing annealing temperature .This is due to the fact that the peaks and the crystalline size of the nanofilm increases with increasing temperature due to lower pressure with this increase. The sharp peaks were appeared in (100), (002), and (101) planes at annealing temperature $500^{\circ} \mathrm{C}$.

From the atomic force microscopy technique, the grain size and average roughness of $\mathrm{ZnO}$ nanofilms prepared at different annealing temperatures were obtained, as shown in Figure-3. From Table-2 the grain size be highest value at the highest annealing temperature, while the average roughness and the root mean square were lowered value. These results indicate the average grain size has a direct relationship with increasing annealing temperature but the average roughness and the root mean square decreasing with increasing of temperature.

The SEM of ZnO nanostructure (cluster structure) deposit on glass substrate using LIP technique at RT, is shown in Figure-4, where the average grain size of $\mathrm{ZnO}$ was around $20 \mathrm{~nm}$.

The transmission spectrum as a function of wavelength in the range of (300-1100) nm for $\mathrm{ZnO}$ nanofilms deposited using laser induced plasma at RT and two annealing temperatures $350^{\circ} \mathrm{C}$ and $500^{\circ} \mathrm{C}$, as shown in Figure-5. It can be noticed from this figure that the transmission spectra generally are high in the visible and infrared regions. The transmittance spectra of all $\mathrm{ZnO}$ nanofilms increase with increasing of annealing temperature this increase is due to the increased crystalline volume resulting from increased nanofilm density. The absorption coefficient as a function of wavelength of $\mathrm{ZnO}$ nanofilms at RT and two annealing temperatures $350^{\circ} \mathrm{C}$ and $500^{\circ} \mathrm{C}$ is shown in Figure-6. These spectra show low absorption in the visible and infrared regions, however, the absorption in the ultraviolet region is high. The absorption coefficient spectra are decreased with increasing the annealing temperature. The optical absorption coefficient constant $(\alpha)$ has been calculated using the following equation [1]:

$$
\alpha=\square 2.303 A / t
$$

Where $A$ is the absorbance and $(t)$ is the thickness of prepared nanofilms that equal $(200 \mathrm{~nm})$. Absorption increases at all temperatures when material layers increase, leading to increased $\mathrm{ZnO}$ crystals, which absorb photon energy [13].

The variation of $(\alpha h v)^{2}$ as a function of photon energy for $\mathrm{ZnO}$ nanofilms at RT and two different annealing temperatures $350^{\circ} \mathrm{C}$ and $500^{\circ} \mathrm{C}$ is shown in Fig. (7). The variation of $(\alpha \mathrm{hv})^{2}$ is estimated by the Tauc's Equation[14]:

$$
(\alpha h v)=A\left(h v-E_{g}\right)^{n}
$$

Where $(A)$ is a constant, $(a)$ absorption coefficient, $(h v)$ is the incident photon energy and $(E g)$ is the optical energy band gap. This equation used $n=1 / 2$ for direct transition [8]. The extrapolation of the linear part of the plot $(a \mathrm{~h} v)^{2}=0$, gives rise on the estimation of the energy gap value of the prepared $\mathrm{ZnO}$ nanofilms. In Fig. (8), the value of the energy gap was found it increases with increasing annealing temperatures from $2.72 \mathrm{eV}$ to $3.25 \mathrm{eV}$. The change in energy gap is calculated by[15]:

$$
\Delta E_{g}=\frac{\hbar^{2} v^{2}}{2 R^{2}}\left(\frac{1}{M e}+\frac{1}{M h}\right)-\frac{\left(1.76 e^{2}\right)}{E R}
$$

where $\left(\Delta \mathrm{E}_{\mathrm{g}}\right)$ is the change in the energy gap, $(\mathrm{R})$ is the radius of the particle, $(\mathrm{E})$ is the static dielectric constant of the matter and $\mathrm{M}_{\mathrm{e}}, \mathrm{M}_{\mathrm{h}}$ is the effective masses of electrons in the conduction band and holes in the valence band respectively. The radius of the particle increases with increasing the annealing because of the increase in the crystalline size $\left(\Delta \mathrm{E}_{\mathrm{g}}\right)$ will increase.

The variation of the extinction coefficient various wavelength of $\mathrm{ZnO}$ nanofilms at $\mathrm{RT}$ and two annealing temperatures $350^{\circ} \mathrm{C}$ and $500^{\circ} \mathrm{C}$ is shown in Fig.(9). The extinction coefficient spectra are decreasing with increasing annealing temperatures this decrease is due to the increasing value of energy gap with annealing temperatures.

The real part of the dielectric constant value depends on the refractive index(n) and the extinction coefficient $(\mathrm{K})$, but the imaginary part depends on the refractive index(n) only. The spectrum of the excited electron can be explained by dielectric constant (real and imaginary parts, Where the imaginary part represents the absorption of energy from the electric field because of the molecules that 
possess the bipolar moment in the material, but the imaginary part represents the low speed of light in the material [16]. The real and imaginary parts are evaluated by the following equations [17]:

$$
\begin{aligned}
\varepsilon_{r} & =\mathrm{n}^{2}-k^{2} \\
\varepsilon \mathrm{i} & =\square 2 n k
\end{aligned}
$$

where $\left(\varepsilon_{r}\right)$ is a real part and $(\varepsilon i)$ is imaginary part of the dielectric constant. Figures-(7, 11) shows the spectra of the real and imaginary part dielectric constant of $\mathrm{ZnO}$ nanofilms at RT and two annealing temperatures $350^{\circ} \mathrm{C}$ and $500^{\circ} \mathrm{C}$. For more details Table- 3 shows the most important value of $\mathrm{ZnO}$ nanofilms prepared using LIP at different annealing temperatures.

\section{Conclusion}

$\mathrm{ZnO}$ nanofilms were easily obtained using laser induced plasma technique at different temperatures (RT, $350^{\circ} \mathrm{C}$ and $500^{\circ} \mathrm{C}$ ). $\mathrm{ZnO}$ nanofilms display hexagonal structure. In AFM characterizations show the grain size (diameter size) increases with increasing temperatures. The band gap of $\mathrm{ZnO}$ nanofilms was increased with increasing the annealing temperature at the same thickness of films.

Table 1-Structural parameters like inter-planar spacing, crystallite size and miller of $\mathrm{ZnO}$ at different

\begin{tabular}{|c|c|c|c|c|c|c|c|c|}
\hline $\begin{array}{l}\mathrm{Ta} \\
\left({ }^{\circ} \mathrm{C}\right)\end{array}$ & $\begin{array}{c}2 \theta \\
\text { (Deg.) }\end{array}$ & $\begin{array}{c}\text { FWHM } \\
\text { (Deg.) }\end{array}$ & $\begin{array}{c}\mathrm{d}_{\mathrm{hkl}} \\
\operatorname{Exp} .(\AA)\end{array}$ & $\begin{array}{l}\text { G.S } \\
(\mathrm{nm})\end{array}$ & hkl & $\begin{array}{c}\mathrm{d}_{\mathrm{hkl}} \\
\text { Std. }(\AA)\end{array}$ & Phase & Card No. \\
\hline \multirow{7}{*}{ RT } & 31.6772 & 0.3323 & 2.8224 & 24.9 & $(100)$ & 2.8137 & Hex. $\mathrm{ZnO}$ & 96-901-1663 \\
\hline & 34.1930 & 0.3797 & 2.6202 & 21.9 & (002) & 2.6035 & Hex. ZnO & 96-901-1663 \\
\hline & 36.1867 & 0.2847 & 2.4803 & 29.4 & $(101)$ & 2.4754 & Hex. $\mathrm{ZnO}$ & 96-901-1663 \\
\hline & 56.5032 & 0.5696 & 1.6274 & 15.8 & (110) & 1.6245 & Hex. $\mathrm{ZnO}$ & 96-901-1663 \\
\hline & 62.8165 & 0.5696 & 1.4781 & 16.3 & (103) & 1.4772 & Hex. $\mathrm{ZnO}$ & 96-901-1663 \\
\hline & 67.9430 & 0.5222 & 1.3785 & 18.3 & (112) & 1.3782 & Hex. $\mathrm{ZnO}$ & 96-901-1663 \\
\hline & 69.1772 & 0.8070 & 1.3569 & 12.0 & (201) & 1.3582 & Hex. $\mathrm{ZnO}$ & 96-901-1663 \\
\hline \multirow{7}{*}{350} & 31.6772 & 0.2848 & 2.8224 & 29.0 & $(100)$ & 2.8137 & Hex. $\mathrm{ZnO}$ & 96-901-1663 \\
\hline & 34.3354 & 0.2373 & 2.6097 & 35.1 & $(002)$ & 2.6035 & Hex. $\mathrm{ZnO}$ & $96-901-1663$ \\
\hline & 36.1392 & 0.2372 & 2.4835 & 35.2 & (101) & 2.4754 & Hex. $\mathrm{ZnO}$ & 96-901-1663 \\
\hline & 47.4367 & 0.3322 & 1.9150 & 26.1 & $(102)$ & 1.9110 & Hex. $\mathrm{ZnO}$ & 96-901-1665 \\
\hline & 56.5506 & 0.3797 & 1.6261 & 23.8 & $(110)$ & 1.6245 & Hex. $\mathrm{ZnO}$ & 96-901-1663 \\
\hline & 62.8165 & 0.4746 & 1.4781 & 19.6 & (103) & 1.4772 & Hex. $\mathrm{ZnO}$ & 96-901-1663 \\
\hline & 67.9430 & 0.3797 & 1.3785 & 25.2 & (112) & 1.3782 & Hex. $\mathrm{ZnO}$ & 96-901-1663 \\
\hline \multirow{9}{*}{500} & 31.7247 & 0.1899 & 2.8182 & 43.5 & $(100)$ & 2.8137 & Hex. $\mathrm{ZnO}$ & 96-901-1663 \\
\hline & 34.3354 & 0.2373 & 2.6097 & 35.1 & $(002)$ & 2.6035 & Hex. $\mathrm{ZnO}$ & 96-901-1663 \\
\hline & 36.2342 & 0.1897 & 2.4772 & 44.1 & $(101)$ & 2.4754 & Hex. $\mathrm{ZnO}$ & 96-901-1663 \\
\hline & 47.5316 & 0.1899 & 1.9114 & 45.7 & (102) & 1.9110 & Hex. $\mathrm{ZnO}$ & 96-901-1665 \\
\hline & 56.5032 & 0.2847 & 1.6274 & 31.7 & (110) & 1.6245 & Hex. $\mathrm{ZnO}$ & 96-901-1663 \\
\hline & 62.8165 & 0.2373 & 1.4781 & 39.2 & (103) & 1.4772 & Hex. $\mathrm{ZnO}$ & 96-901-1663 \\
\hline & 67.8956 & 0.3797 & 1.3794 & 25.2 & (112) & 1.3782 & Hex. $\mathrm{ZnO}$ & $96-901-1663$ \\
\hline & 69.0348 & 0.3323 & 1.3594 & 29.0 & (201) & 1.3582 & Hex. $\mathrm{ZnO}$ & 96-901-1663 \\
\hline & 72.7848 & 0.4746 & 1.2983 & 20.8 & (004) & 1.3017 & Hex. $\mathrm{ZnO}$ & 96-901-1663 \\
\hline
\end{tabular}
annealing temperatures. 


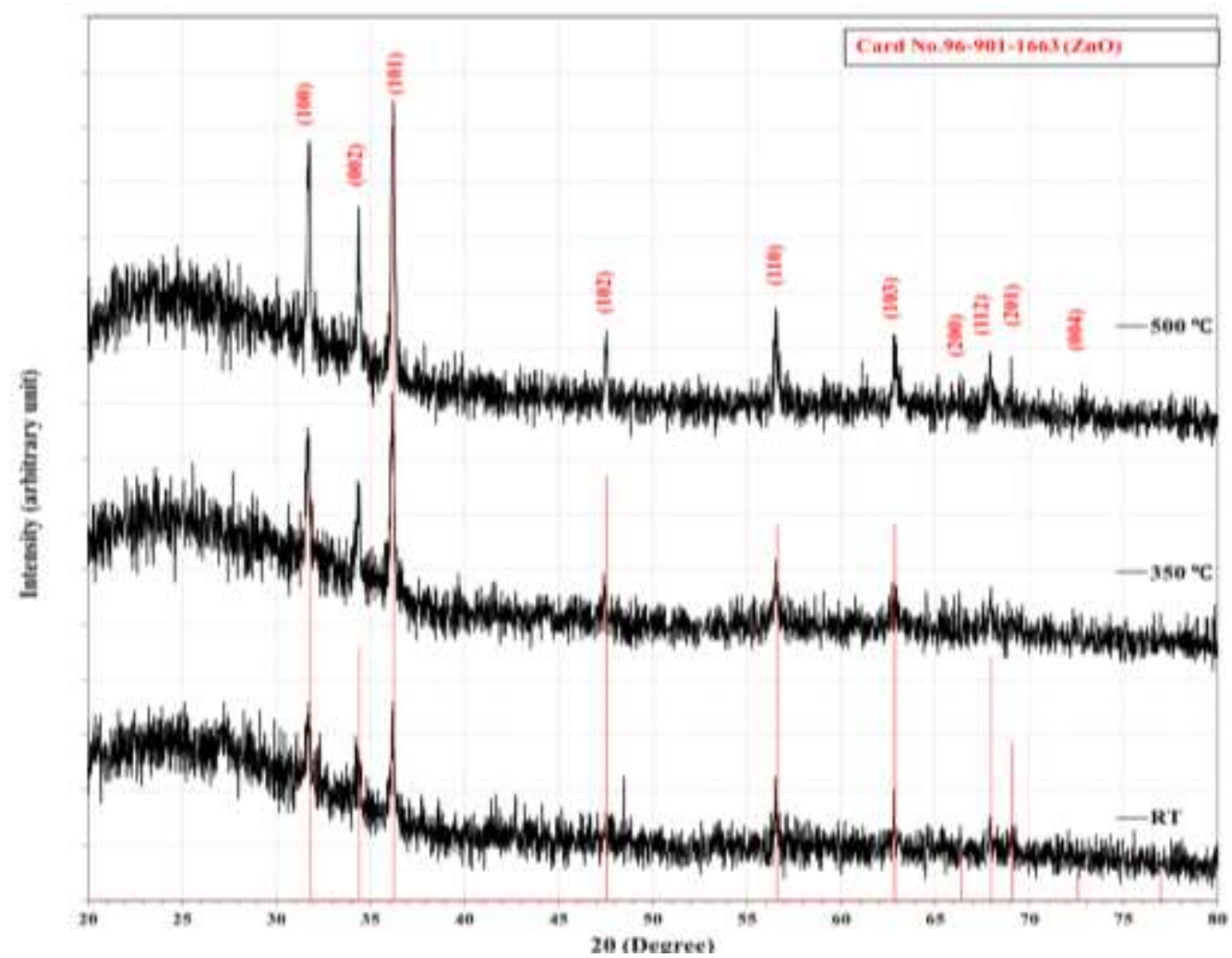

Figure 2-X-ray diffraction patterns of $\mathrm{ZnO}$ with different temperatures $\left(\mathrm{RT}, 350^{\circ} \mathrm{C}, 500^{\circ} \mathrm{C}\right)$

Table 2-Average roughness, grain size and R.M.S for the $\mathrm{ZnO}$ thin films at different temperatures obtained from (AFM).

\begin{tabular}{|c|c|c|c|c|}
\hline Sample & Temperature & $\begin{array}{c}\text { Ave. grain } \\
\text { size(nm) }\end{array}$ & Ave.roughness(nm) & R.M.S(nm) \\
\hline $\mathrm{ZnO}$ & $\mathrm{RT}$ & 52.26 & 3.51 & 4.06 \\
\hline $\mathrm{ZnO}$ & $350^{\circ} \mathrm{C}$ & 82.93 & 2.66 & 3.1 \\
\hline $\mathrm{ZnO}$ & $500^{\circ} \mathrm{C}$ & 87.75 & 1.19 & 1.37 \\
\hline
\end{tabular}

RT

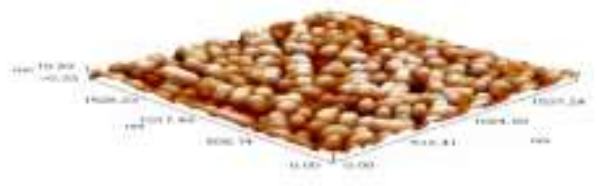

$\mathrm{T}=500^{\circ} \mathrm{C}$

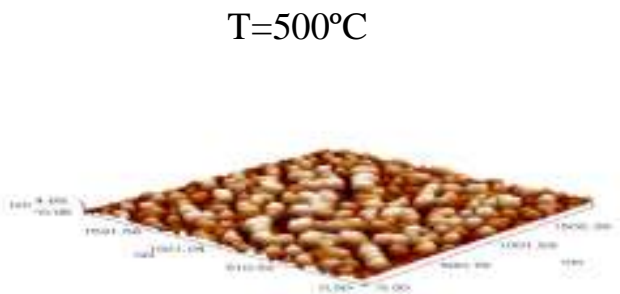

$\mathrm{T}=350^{\circ} \mathrm{C}$

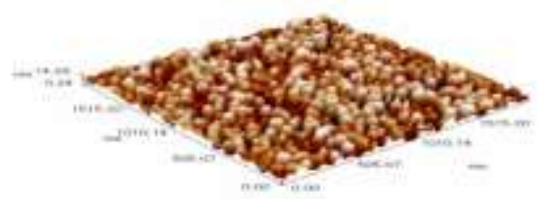

Figure 3-3D image for surface morphology of $\mathrm{ZnO}$ nanofilms analyzed by AFM test at different temperatures. 


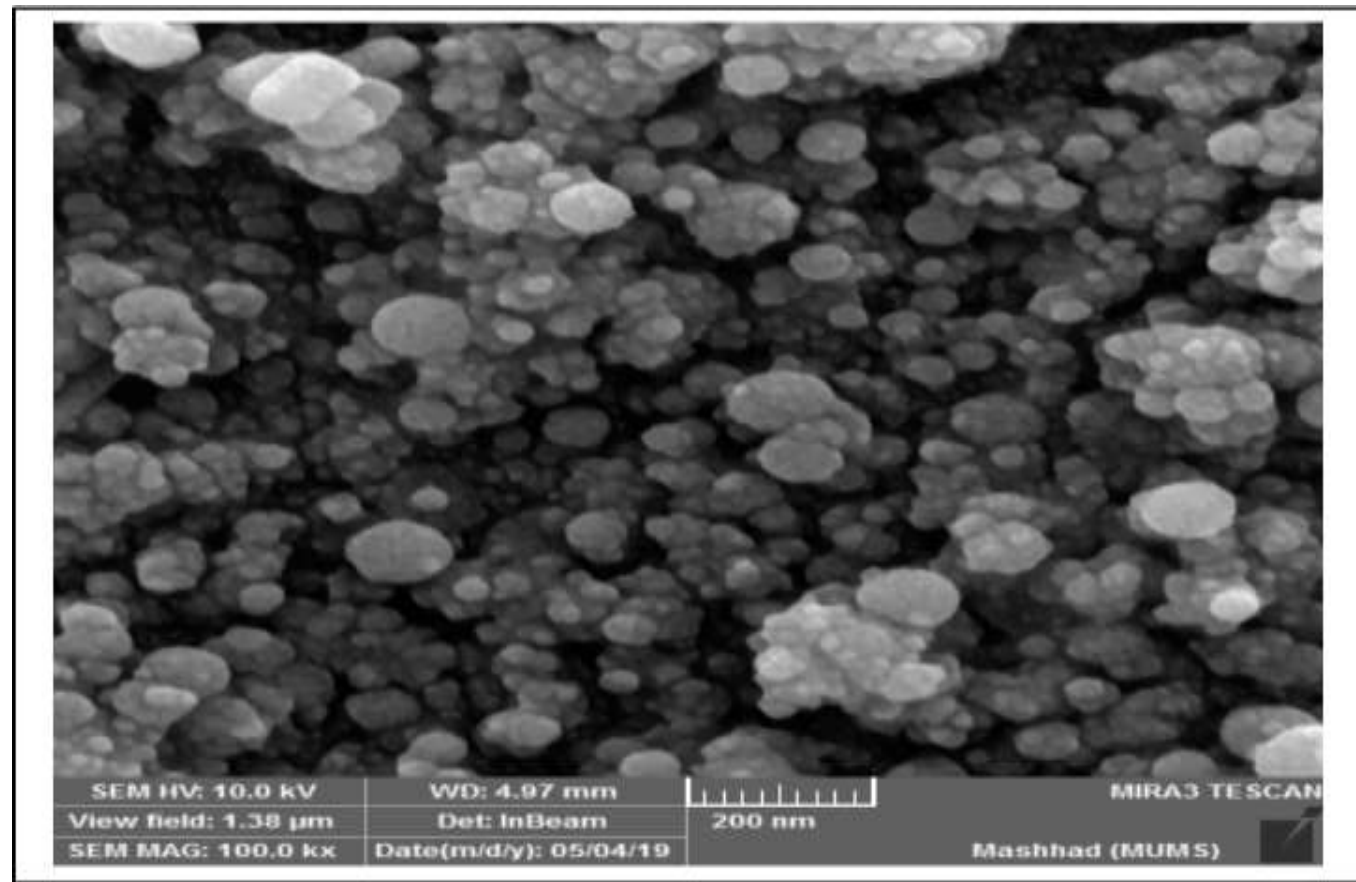

Figure 4-SEM of ZnO nanostructure (cluster structure) deposit on glass substrate at RT.

Table 3-Transmittance spectra (T) for nano-films, Absorption coefficient, refractive index(n), Extinction coefficient(K)and Dielectric Constant in the wavelength of $200 \mathrm{~nm}$ with different temperatures

\begin{tabular}{|c|c|c|c|c|c|c|c|}
\hline $\begin{array}{c}\text { Temperature of } \\
\mathrm{ZnO}\end{array}$ & $\mathrm{T} \%$ & $\alpha\left(\mathrm{cm}^{-1}\right)$ & $\mathrm{K}$ & $\mathrm{n}$ & $\varepsilon_{\mathrm{r}}$ & $\varepsilon_{\mathrm{i}}$ & $\mathrm{Eg}(\mathrm{eV})$ \\
\hline $\mathrm{RT}$ & 2.95 & 39164 & 0.171 & 8.709 & 75.809 & 2.987 & 2.00 \\
\hline $350^{\circ} \mathrm{C}$ & 10.34 & 25209 & 0.110 & 10.312 & 106.316 & 2.277 & 2.25 \\
\hline $500^{\circ} \mathrm{C}$ & 36.32 & 11254 & 0.049 & 6.525 & 42.576 & 0.643 & 2.37 \\
\hline
\end{tabular}

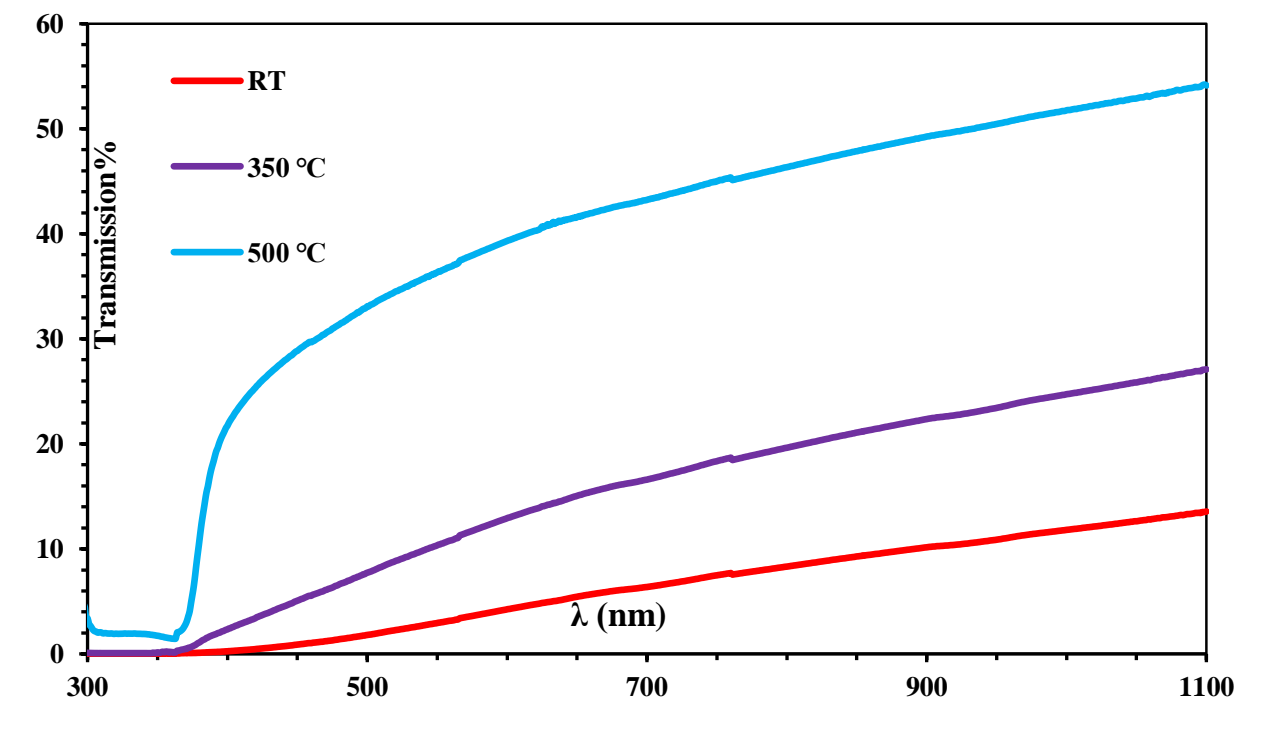

Figure 5-The variation of the transmittance spectra as function of wavelength for $\mathrm{ZnO}$ nano-films at different temperatures. 


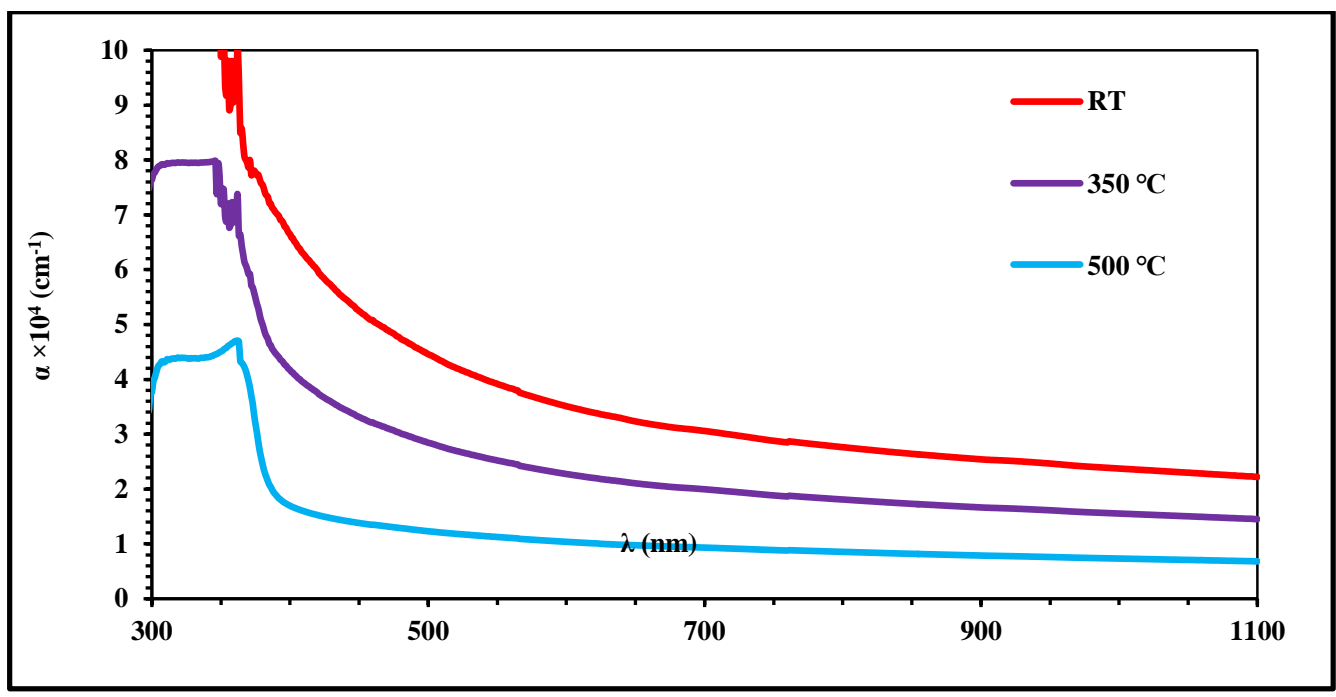

Figure 6-Absorption coefficient as a function of wavelength for $\mathrm{ZnO}$ nano-films at different temperatures

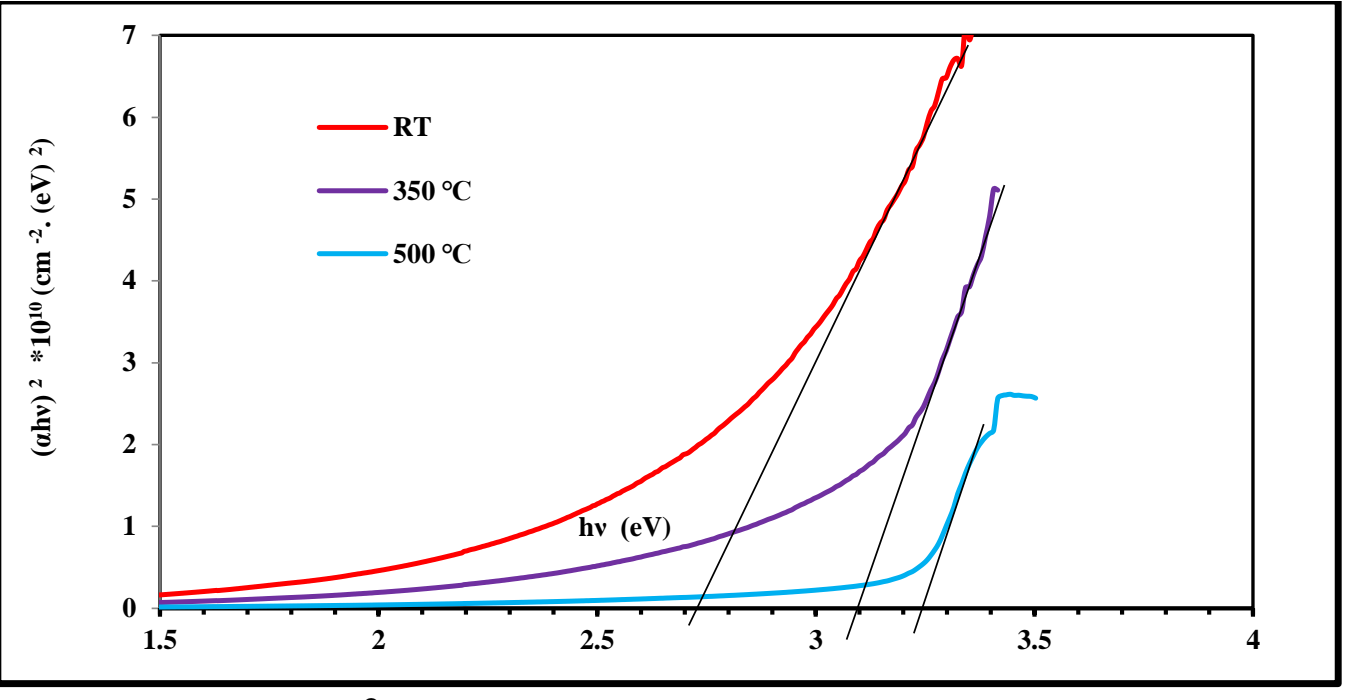

Figure 7-The variation of $(\alpha h v)^{2}$ as a function of photon energy for $\mathrm{ZnO}$ nanofilms at different temperatures.

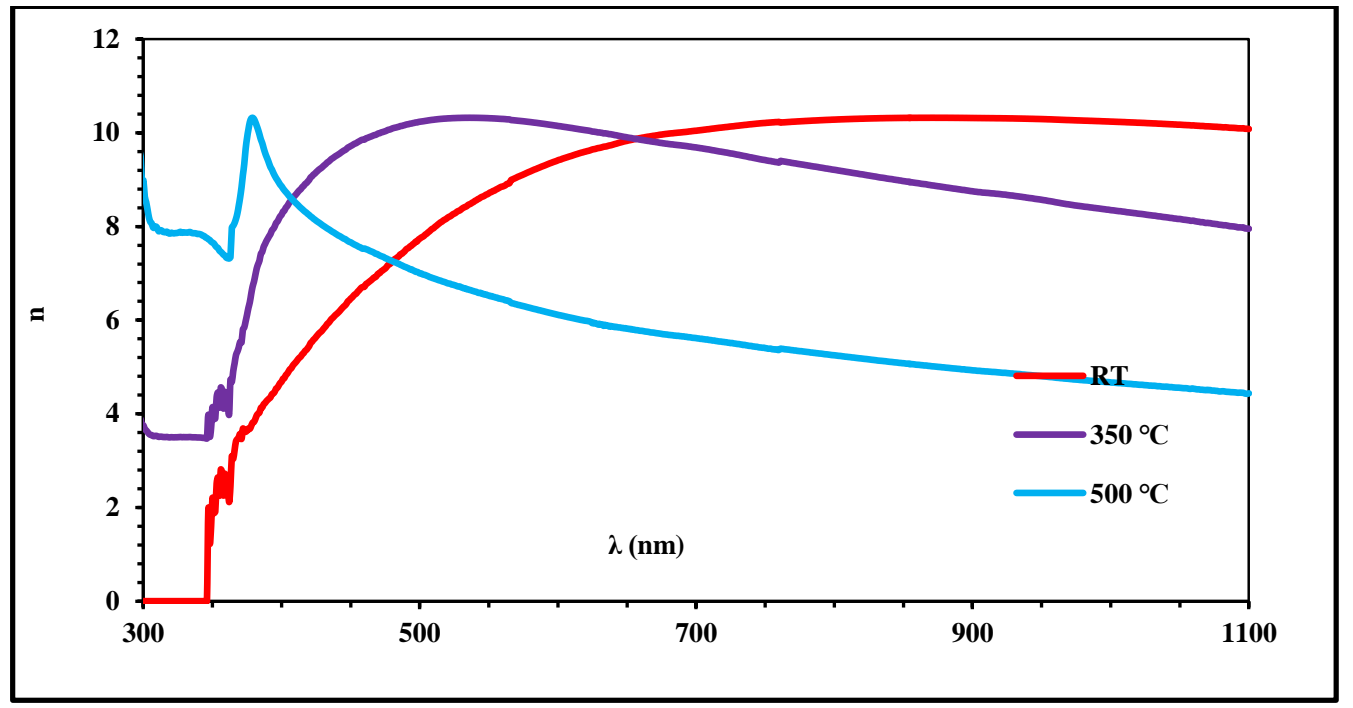

Figure 8-The variation of refractive index as a function of wavelength for $\mathrm{ZnO}$ films at different temperatures. 


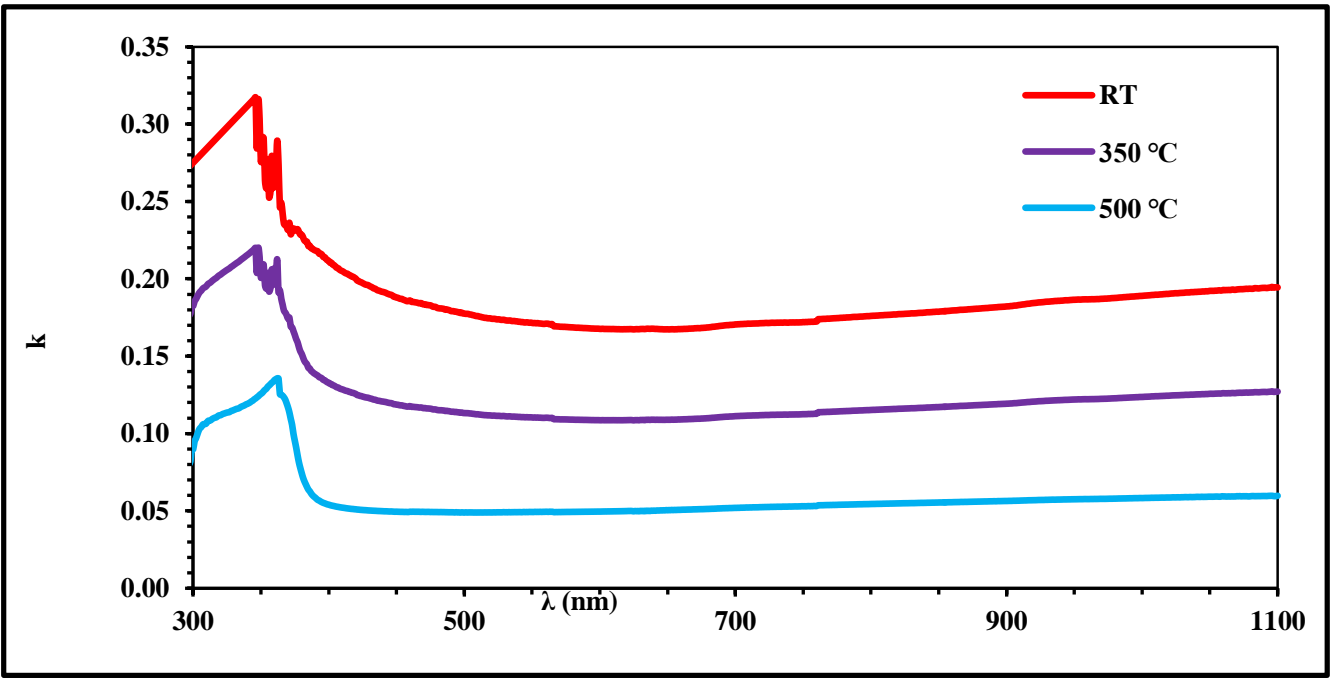

Figure 9-The variation of the extinction coefficient various wavelength for $\mathrm{ZnO}$ nanofilms at different temperatures.

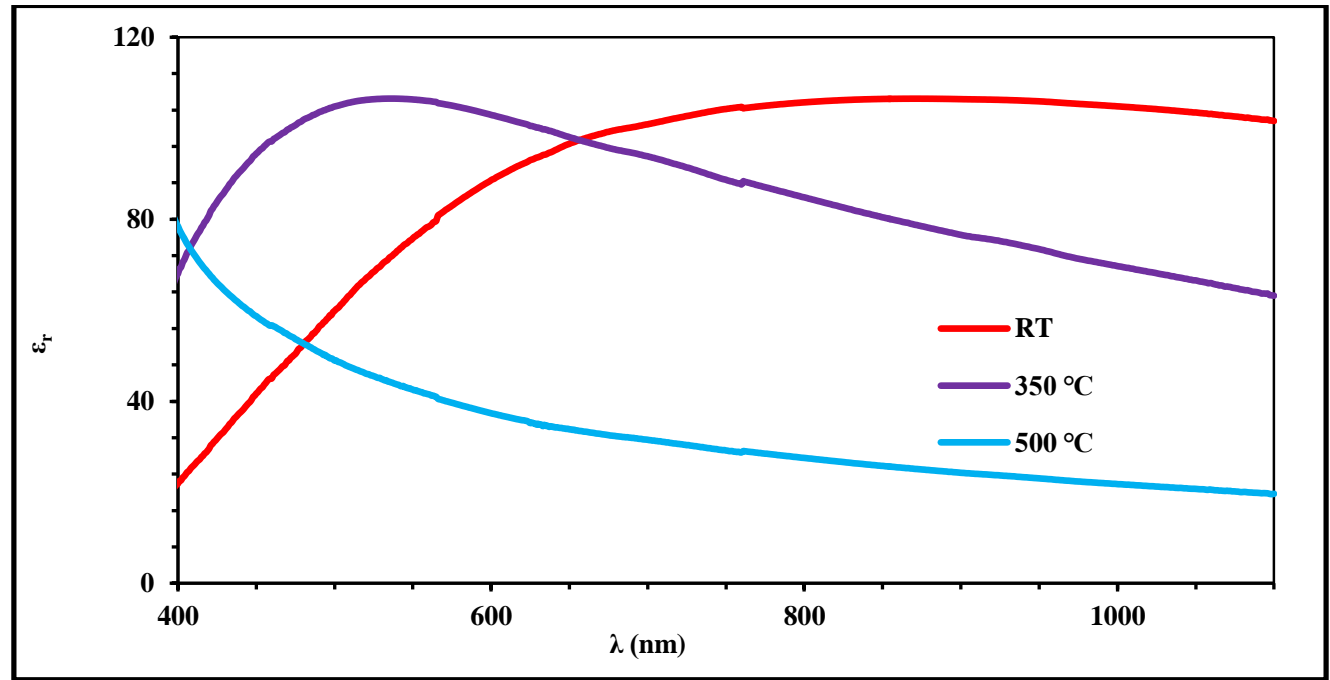

Figure 10-The variation of the real part of Dielectric constant ( $\varepsilon r)$ for $\mathrm{ZnO}$ nanofilms at different temperatures.

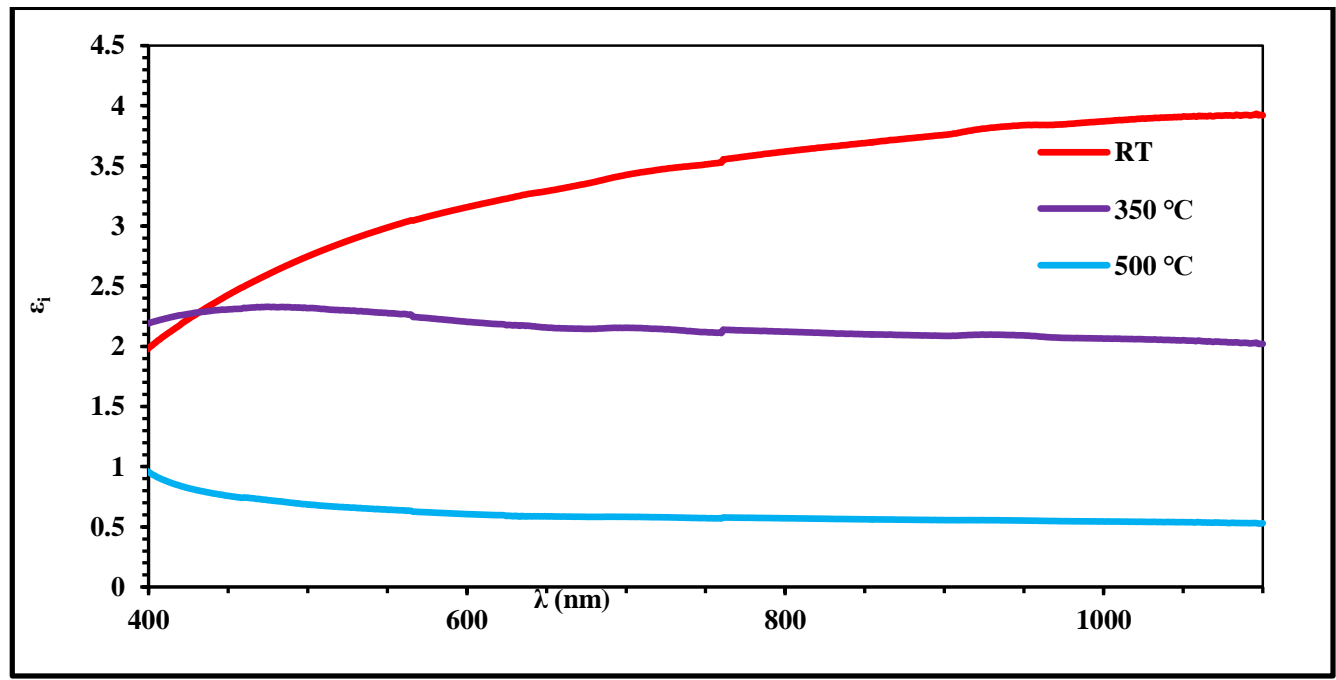

Figure 11-The variation of the imaginary part of Dielectric constant (zi) for $\mathrm{ZnO}$ nanofilms at different temperatures. 


\section{Reference}

1. Srinatha, N., Raghu, P., Mahesh, H.M. and Basavaraj, A. 2017. Spin-coated Al-doped ZnO thin films for optical applications: Structural, micro-structural, optical and luminescence studies, Journal of Alloys and Compounds, 722: 888-895

2. Hasabeldaim, E., Ntwaeaborwa, O.M., Kroon, R.E., Coetsee, E. and Swart, H.C. 2017. Effect of substrate temperature and post annealing temperature on $\mathrm{ZnO}$ : Zn PLD thin film properties, Optical Materials, xxx: 1-11.

3. Zawadzka, A., Płóciennik, P., El Kouari, Y., Bougharraf, H. and Sahraoui, B. 2016. Linear and nonlinear optical properties of $\mathrm{ZnO}$ thin films deposited by pulsed laser deposition, Journal of Luminescence, 169: 483-49.

4. Shan, F.K., Shin, B.C., Jang, S.W. and Yu, Y.S. 2004. Substrate effects of ZnO thin films prepared by PLD technique, Journal of the European Ceramic Society, 24: 1015-1018.

5. Ganesh Kumar Mani and John Bosco Balaguru Rayappan, 2015, A highly selective and wide range ammonia sensor Nanostructured ZnO:Co thin film, Materials Science and Engineering B 191:41-50.

6. Larbah, Y., Adnane, M. and Sahraoui, T. 2015. Effect of substrate temperature on structural and optical properties of spray deposited $\mathrm{ZnO}$ thin films, Materials Science-Poland, 33(3): 491-496.

7. Shan, F.K. and Yu, Y.S. 2004. Band gap energy of pure and Al-doped $\mathrm{ZnO}$ thin films, Journal of the European Ceramic Society, 24: 1869-1872.

8. Craciun, V., Elders, J., Gardeniers, J.G.E. and Ian Boyd, W. 1994. Characteristics of high quality ZnO thin films deposited by pulsed laser deposition, Appl. Phys. Lett., 65: 23.

9. Vanalakar, S.A., Agawane, G.L. Shin, S.W., Suryawanshi, M.P., Gurav , K.V., Jeon , K.S., Patil , P.S., Jeong , C.W., Kim , J.K., Kim, J.H. 2015. A review on pulsed laser deposited CZTS thin films for solar cell applications, Journal of Alloys and Compounds, 619: 109-121.

10. Fan, X.M., Lian, J.S., Guo, Z.X. and Lu, H.J. 2005. Microstructure and photoluminescence properties of $\mathrm{ZnO}$ thin films grown by PLD on $\mathrm{Si}\left(\begin{array}{lll}1 & 1 & 1\end{array}\right)$ substrates, Applied Surface Science, 239: 176-181.

11. Vinod Kumar, Odireleng M. Ntwaeaborwa, Hendrik C. Swart, 2016. Deep level defect correlated emission and $\mathrm{Si}$ diffusion in $\mathrm{ZnO}: \mathrm{Tb}^{3+}$ thin films prepared by pulsed laser deposition, Journal of Colloid and Interface Science, 465: 295-303 .

12. Scherrer, p. 1918. Göttinger Nachrichten Gesell. 2: 98.

13. Dahrul, M., Husin, A. and Irzaman, 2015. Preparation and optical properties study of $\mathrm{CuO}$ thin film as applied solar cell on LAPAN-IPB Satellite, Procedia Environmental Sciences, 33: 661 667.

14. Klochko, N.P., Klepikova, K.S., Kopach, V.R., Tyukhov, I.I., Zhadan, D.O., Khrypunov, G.S., Petrushenko, S.I., Dukarov, S.V., Lyubov, V.M., Kirichenko, M.V. and Khrypunova, A.L. 2018. Semitransparent $\mathrm{p}-\mathrm{CuI}$ and $\mathrm{n}-\mathrm{ZnO}$ thin films prepared by low temperature solution growth for thermoelectric conversion of near-infrared solar light, Solar Energy, 171: 704-715.

15. Agbo, P.E. and Nnabuchi, M.N. 2011. Core-Shell $\mathrm{TiO}_{2} / \mathrm{ZnO}$ Thin film: Preparation, characterization and effect of temperature on some selected properties, Chalcogenide Letters, $\mathbf{8}$ : 273-282.

16. Usha, K., Sivakumar, R. and Sanjeeviraja, C. 2013. Optical constants and dispersion energy parameters of $\mathrm{NiO}$ thin films prepared by radio frequency magnetron sputtering technique, J. Appl. Phys., 114: 123501.

17. Ganesh, V., Yahia, I.S., AlFaify, S. and Mohd, S. 2016. Sn-doped ZnO nanocrystalline thin films with enhanced linear and nonlinear optical properties for optoelectronic applications, Journal of Physical and Chemistry of Solids, pp: 1-32. 